\title{
La cruz bajo secuestro. Una mirada a la teología de la cruz desde la teología de la liberación*
}

\author{
“El dolorismo es una abominación y una caricatura de la vida cristiana \\ que consiste en buscar el sufrimiento, o complacerse en él, con el pre- \\ texto de que Jesús sufrió."
}

Аbbé Pierre

\author{
Álvaro Mejía Góez** \\ Loida Sardiñas Iglesias***
}

Recibido: 16 de septiembre de 2012 • Aprobado: 18 de diciembre de 2012

\section{Resumen}

Este artículo hace parte de una serie de trabajos del mismo autor, que llevan el genitivo de "bajo secuestro": "María bajo secuestro", "El infierno bajo secuestro" y el presente trabajo. Lo que se busca por medio de ellos, es ayudar a tomar conciencia de que, en ocasiones, el dogma cristiano ha sido llevado a niveles de abstracción tan alejados de sus orígenes, que

* Este artículo es producto de una investigación de los autores en la Universidad de San Buenaventura.

* El profesor Álvaro Mejía Gómez es Doctorando en Teología Dogmática de la Universidad Pontificia Bolivariana de Medellín; es magíster en Teología Fundamental de la Universidad Pontificia Gregoriana de Roma. Actualmente es profesor de cátedra en la Facultad de Teología de la USTA y profesor en el Instituto Bíblico Pastoral Latinoamericano de la Uniminuto, Bogotá. Pertenece al grupo Etihikós de la Facultad de Teología de la Universidad Santo Tomás. Correo: almego68@hotmail.com

*** La profesora Loida Lucía Sardiñas Iglesias es Doctora en Teología de la Universidad de Hamburgo en Alemania; actualmente es docente de la Pontificia Universidad Javeriana de Bogotá. Pertenece al grupo Etihikós de la Facultad de Teología de la Universidad Santo Tomás. Correo: loidasardinas@gmail.com 
han servido para esclavizar, dominar y deshumanizar la experiencia evangélica de muchos hombres y mujeres sencillos. La expresión "bajo secuestro" quiere apuntar entonces, a la necesidad de liberar el dogma para que cumpla su función de liberación y humanización. Estos trabajos están todos en la vía de inspiración del teólogo uruguayo Juan Luis Segundo, quien en la lógica de la Teología de la Liberación nos propone un "dogma que libere".

Palabras clave: cruz, teología, liberación, sufrimiento, dolorismo.

\title{
The cross under seizure. A look at theology of the cross from the liberation theology
}

\begin{abstract}
This article is part of a series of papers from the same author, which have the genitive "seizure". "Maria under seizure", "Hell under seizure" and this paper, want to help to create awareness that on occasions the Christian dogma has been carried to levels of abstraction so far from their origins, that they have served to enslave, dominate and dehumanize the evangelical experience of many ordinary men and women. The expression "seizure" wants to aim, then, at the necessity of liberating the dogma so it can fulfill its function of liberation and humanization. All these papers are in the path and inspiration of Uruguayan theologian Juan Luis Segundo, who in the logic of Liberation Theology proposes a "dogma that liberates".
\end{abstract}

Keywords: Cross, theology, liberation, suffering, painism.

\section{Introducción}

Contó en una ocasión Leonardo Boff, que su hermano Clodovis lo invitaba con frecuencia a pasar vacaciones en su parroquia, y de paso, colaboraba con algunas charlas a los campesinos feligreses habituales de la parroquia. En una ocasión, Leonardo preguntó a los asistentes: “¿cómo nos salvó Jesucristo?” La respuesta fue casi unánime: "a través de su sufrimiento y su muerte en la bendita santa cruz". La respuesta generalizada, llevó a Leonardo Boff, a explicar que la salvación debía entenderse en el conjunto de toda la vida de Jesús de Nazaret; desde su encarnación, pasando por sus signos y palabras, sus actitudes mesiánicas, su preferencia y amistad con los excluidos, por su crítica a la religión instituida, etc.; todo en su conjunto. Y no solo unos cuantos momentos de Jesús crucificado, 
podrían ser determinantes para la salvación de todos los hombres de todos los tiempos (Segundo, 1982).

Si alguna doctrina tuvo un desarrollo vertiginoso, desde sus orígenes hasta nuestros días, es la de la cruz, y con ella todas sus vertientes en torno a la teoría de la redención, de la justificación, de la muerte vicaria, de la necesidad del sufrimiento, etc.

Rápidamente se pasó de una comprensión de la muerte de Jesús como algo ignominioso, vergonzante, humillante y despiadado, a una concepción de la muerte de Cristo como acontecimiento salvador y liberador "por nuestros pecados". La cruz pasó de ser un instrumento de tortura a un signo de vida y victoria; a ser objeto de veneración, y en ocasiones se convirtió en pretexto ideológico para justificar el dolorismo y hasta la dominación. Expresiones como "cargar la cruz", "esta es la cruz que me tocó cargar", "esta es la cruz que Dios me puso"; etc., son una muestra de los distintos niveles que la doctrina de la cruz adquirió en la teología y en la religiosidad popular de nuestros pueblos latinoamericanos.

Como se dijo anteriormente, este artículo hace parte de una serie de trabajos del mismo autor (Góez, 2007), que llevan el genitivo de "bajo secuestro": "María bajo secuestro", "El infierno bajo secuestro" y el presente trabajo. Éstos quieren ayudar a tomar conciencia de que en ocasiones, el dogma cristiano ha sido llevado a niveles de abstracción tan alejados de sus orígenes, que han servido para esclavizar, dominar y deshumanizar la experiencia evangélica de muchos hombres y mujeres sencillos. La expresión "bajo secuestro" apunta a la necesidad de liberar el dogma, para que cumpla su función de liberación y humanización. Dichos trabajos se encuentran en la vía e inspiración del teólogo uruguayo Juan Luis Segundo, quien en la lógica de la Teología de la Liberación nos propone un “dogma que libere” (Segundo, 1989).

\section{De la pasión de Cristo a la cruz en Pablo}

Los textos evangélicos sinópticos, apuntan a mostrar que la crucifixión de Jesús es un evento doloroso, inesperado y desconcertante. El final del maestro era trágico, parecía como un increíble error. “¿Qué ha hecho el profeta de la compasión de Dios para terminar en ese suplicio que solo se aplicaba a esclavos criminales o a rebeldes peligrosos para el orden impuesto por Roma? ¿Qué delito ha cometido el curador de enfermos para ser torturado en una cruz? ¿Quién teme al maestro que predica el amor a los enemigos? ¿Quién se siente amenazado por su actuación y su mensaje? ¿Por qué se le mata?” (Pagola, 2007) La exégesis, y toda la 
crítica histórica, están de acuerdo en que no existe en los evangelios una teología de la cruz en su comprensión actual, sino unos datos históricos incontrovertibles, que ven en la muerte de Jesús el fracaso de un proyecto; tal vez el pasaje de los discípulos de Emaús, sea emblemático para iluminar esta experiencia de frustración y desconcierto.

Efectivamente, la muerte en cruz era utilizada en el imperio romano como una de las ejecuciones más terribles y temidas, junto con la hoguera y ser devorado por las fieras (damnatio ad bestias). "La crucifixión no era una simple ejecución, sino una lenta tortura. Al crucificado no se le dañaba directamente ningún órgano vital, de manera que su agonía podía prolongarse durante largas horas, hasta días. Por otra parte, era normal combinar el castigo básico de la crucifixión con humillaciones y tormentos diversos. Los datos son escalofriantes. No es extraño mutilar al crucificado, vaciarle los ojos, quemarlo, flagelarlo o torturarlo de diversas formas antes de colgarlo en la cruz. La manera de llevar a cabo la crucifixión se prestaba, sin más, al sadismo de los verdugos. Séneca habla de hombres crucificados cabeza abajo o empalados en el poste de la cruz de manera obscena" (Pagola, 2007).

En este estado de cosas, resultaría extraño que Jesús hubiera dado a su muerte un sentido teológico sacrificial-redentor, más allá de lo que históricamente se podía entender de esta forma de morir. Por eso José Antonio Pagola dice con claridad que "Jesús no elaboró ninguna teoría sobre su muerte, no hizo teología sobre su crucifixión. [...] Jesús no interpretó su muerte desde una perspectiva sacrificial. No la entendió como un sacrificio de expiación ofrecido al Padre. No era su lenguaje. Nunca había vinculado el reino de Dios a las prácticas cultuales del templo; nunca había entendido su servicio al proyecto de Dios como un sacrificio cultual" (Pagola, 2007). Como lo veremos más adelante, será la teología sacrificial de la alta edad media, la que introducirá el lenguaje en categorías procedentes del mundo de la expiación, que ante la muerte del justo, del perfectamente justo, tendrá que considerar la posibilidad de que esa muerte estuviera dentro del plan de Dios para reparar el pecado del hombre en sus orígenes.

De todas maneras, si Jesús no predicó la cruz como el final feliz de su proyecto del reino de Dios, es posible ver en los evangelios una reflexión pos pascual que intentaba comprender lo sucedido, y convertirlo en "una ganancia" en la predicación. Seguramente las palabras puestas por los evangelistas en boca de Jesús agonizante, son una muestra de esta teología primigenia que quería darle sentido a esa muerte. Ya la imposibilidad de hacer concordar las "ipsissima verba Iesu" en esta materia, nos dan a entender que más allá de la historicidad de esas 
palabras, existe una intencionalidad teológica en ponerlas en la escena. Según Marcos y su paralelo en Mateo, Jesús grita con fuerte voz: “iDios mío, Dios mío! ¿por qué me has abandonado?". Lucas, parece ignorar estas palabras y dice que Jesús gritó: "Padre, en tus manos pongo mi espíritu". Pero según Juan, antes de morir, Jesús dice: "Tengo sed", y, después de beber el vinagre que le ofrecieron, exclamó: “Todo está cumplido”. ¿Qué significado tienen estas palabras? ¿Cuál es la intención teológica del evangelista? Seguro que tenían una finalidad catequética para la comunidad de destino del escrito.

Es evidente que en Juan se encuentra un texto más elaborado. En la escena de la crucifixión no hay dolor y sufrimiento, todo parece en una tensa calma; no hay gritos estentóreos, solo unas exclamaciones suaves y serenas: "tengo sed", "todo está cumplido". A los destinatarios del evangelio les debe quedar claro que "ser elevado a la cruz" es el camino para "volver al Padre" y entrar en su gloria. Ese cáliz es imposible rechazarlo, ya que está en la voluntad del Padre, eso solo demuestra la fidelidad de Jesús hasta el final. "Su muerte no es la bajada al sheol, sino su «paso de este mundo al Padre». En las comunidades cristianas nadie lo ponía en duda" (Pagola, 2007).

Así pues, los evangeliosnos proporcionan una primera conclusión importante, para sustentar nuestra propuesta de la necesidad de liberar la teología de la cruz, de cualquier asomo de dolorismo y justificación irracional del sufrimiento. Digámoslo con el staurólogo Luis Armendáriz:

No murió, pues, Jesús rechazado por Dios, sino eliminado por aquéllos cuyo mundo de valores desmontaba y a los que privaba de poder. No es la cruz de Cristo un conflicto metafísico entre el bien y el mal, sino el fruto de un choque de dos ideas sobre Dios. Y es también la consecuencia de la libertad de Jesús y de su antimesianismo. [...] Hay que concentrar la atención en Jesús, no en la cruz. «Parece necesario renunciar a la cruz para fijarnos en el Crucificado» (Machuca, 1977).

Ahora bien, no se puede olvidar la función tan importante que cumple el acontecimiento de la resurrección de Jesucristo, como clave hermenéutica para interpretar la muerte en cruz. Sólo desde esta clave se supera la tragedia de la muerte, y ella adquiere un sentido nuevo para la comunidad cristiana; esta clave sigue siendo muy importante hoy, precisamente si queremos liberar la teología de la cruz de esos niveles de dolorismo a los que la religiosidad la ha llevado. Como lo veremos más adelante, la resurrección es la clave más importante para la Teología de la Liberación (TdL), para entender la superación que debemos hacer 
del sufrimiento justificado desde la cruz, hacia la idea de la resurrección como la rehabilitación de la víctima. Efectivamente, Michel Quesnel afirma:

La resurrección de Jesús de Nazaret, eje de la fe cristiana, fue, desde que se impuso a los discípulos, el punto de partida de una reflexión sobre el sentido de su muerte. [...] Si el Crucificado se había convertido en el Resucitado, su misma muerte adquiría una dimensión distinta. No era solamente muerte; era «muerte por»: por algo o por alguien. Esto es lo que expresaron breves fórmulas llamadas «confesiones de fe», entre las cuales la más célebre es un texto oral con ritmo reproducido por Pablo en la primera carta a los Corintios: «Cristo murió por nuestros pecados según las Escrituras; fue sepultado y resucitó al tercer día según las Escrituras; se apareció a Pedro y luego a los Doce» (1 Cor: 15, 3-5) (Berder \& otros, 2004).

Pasamos así a la concepción paulina de muerte y cruz. En Pablo encontramos, ciertamente, un desarrollo doctrinal muy importante en relación a la idea de sacrificio. Aunque nadie puede negar el genio teológico que hay en Pablo, también es cierto que encontramos posturas y fórmulas ambiguas que resaltan el valor de la cruz, pero que al mismo tiempo permiten imaginar un Dios perverso, que entrega a su hijo a la muerte para reparar una ofensa hecha a él (Berder \& otros, 2004). Más allá de las posteriores interpretaciones que las diversas escuelas paulinas han hecho, lo que sí queda claro es que en el corpus paulino ya encontramos una teología de la cruz, mucho más trabajada que los evangelios sinópticos. Vale la pena citar aquí la catequesis del Papa Benedicto XVI, en la audiencia general del 29 de octubre de 2008, dedicada al tema de la "teología de la cruz en la predicación de San Pablo".

La primera idea fuerte que aparece en la catequesis del Papa es que "para san Pablo la cruz tiene un primado fundamental en la historia de la humanidad"; y la razón es que, para Pablo, la cruz remite necesariamente a la salvación. Esta idea aparece esencial y primaria en la predicación del apóstol; y se ve más claramente en las cartas dirigidas a la comunidad cristiana de Corinto. "Frente a una Iglesia donde había, de forma preocupante, desórdenes y escándalos, donde la comunión estaba amenazada por partidos y divisiones internas que ponían en peligro la unidad del Cuerpo de Cristo, san Pablo se presenta no con sublimidad de palabras o de sabiduría, sino con el anuncio de Cristo, de Cristo crucificado" (XVI, 2008). 
Otra idea que sobresale en la catequesis de Benedicto XVI, es el de la resurrección como clave hermenéutica, presente en Pablo y en las mismas comunidades cristianas fundadas por el apóstol. Afirma el Papa que:

Las primeras comunidades cristianas, a las que san Pablo se dirige, saben muy bien que Jesús ya ha resucitado y vive; el Apóstol quiere recordar, no sólo a los Corintios o a los Gálatas, sino a todos nosotros, que el Resucitado sigue siendo siempre Aquel que fue crucificado. El "escándalo" y la "necedad" de la cruz radican precisamente en el hecho de que donde parece haber sólo fracaso, dolor, derrota, precisamente allí está todo el poder del Amor ilimitado de Dios, porque la cruz es expresión de amor y el amor es el verdadero poder que se revela precisamente en esta aparente debilidad (XVI, 2008).

Una tercera idea parte de una pregunta: “¿Pero por qué san Pablo, precisamente de esto, de la palabra de la cruz, hizo el punto fundamental de su predicación?" (XVI, 2008). La respuesta la encontramos en la primera carta a los corintios. La lógica de Dios no es la nuestra; lo que aparece débil para el hombre es fuerza para Dios (cf: 1 Co 1, 24); idea que está en la misma lógica que plantea Jesús en las bienaventuranzas. Pablo traducirá este espíritu en la frase: “La necedad divina es más sabia que la sabiduría de los hombres, y la debilidad divina, más fuerte que la fuerza de los hombres" (1 Co: 1, 25).

El Crucificado desvela, por una parte, la debilidad del hombre; y, por otra, el verdadero poder de Dios, es decir, la gratuidad del amor: precisamente esta gratuidad total del amor es la verdadera sabiduría. San Pablo lo experimentó incluso en su carne, como lo testimonia en varios pasajes de su itinerario espiritual, que se han convertido en puntos de referencia precisos para todo discípulo de Jesús: "Él me dijo: “Mi gracia te basta, que mi fuerza se muestra perfecta en la flaqueza" (2 Co: 12, 9); y también: "Ha escogido Dios lo débil del mundo para confundir lo fuerte" (1 Co: 1, 28). El Apóstol se identifica hasta tal punto con Cristo que también él, aun en medio de numerosas pruebas, vive en la fe del Hijo de Dios que lo amó y se entregó por sus pecados y por los de todos (cf. Ga 1, 4; 2, 20). Este dato autobiográfico del Apóstol es paradigmático para todos nosotros (XVI, 2008).

Una cuarta y última idea importante en la catequesis del Papa, es el carácter universal y personal que adquiere la muerte y la cruz de Jesús para Pablo 
y para nosotros. La experiencia profunda de conversión de Pablo, lo lleva a experimentar la importancia de la persecución por causa de Cristo. En este encuentro de Pablo con Cristo en el camino de Damasco, "le quedó muy claro el significado central de la cruz: comprendió que Jesús había muerto y resucitado por todos y por él mismo. Ambas cosas eran importantes; la universalidad: Jesús murió realmente por todos; y la subjetividad: murió también por mí. En la cruz, por tanto, se había manifestado el amor gratuito y misericordioso de Dios" (XVI, 2008).

\section{El siglo XV: inicio de una devoción "dolorista". "La imitación de Cristo" de Tomás de Kempis: un ejemplo paradigmático}

Hemos dado un salto largo en el tiempo dentro de esta investigación, y hemos obviado dedicar un apartado a la teología de la cruz en los padres de la Iglesia. Básicamente se debe a que, desde los padres apostólicos en adelante, la teología de la cruz no será diversa a la tradición paulina, y estará inspirada por la situación de persecución, martirio y testimonio que vivieron las primitivas comunidades cristianas en el imperio romano. La categoría "Kénosis" se desarrollará ampliamente en la teología patrística, para denotar la condición de anonadamiento por parte del Hijo de Dios, que se entrega voluntariamente para rescate de todos.

El salto lo hemos dado hasta finalizada la edad media, porque en esta época, ya es mucho más evidente un cambio en la teología de la cruz. Gracias a la teología sacramental de Pedro Lombardo en el siglo XII, la eucaristía tenía un fuerte acento sacrificial, y la cruz ocupaba el centro icónico en las celebraciones. La eucaristía como sacrificio incruento, irradiaba el resto de prácticas cultuales y piadosas, hasta permear toda la espiritualidad cristiana medieval. No es fortuito que en esta época se comercializaran con frecuencia reliquias falsificadas de astillas de la cruz de Cristo, pedazos de los clavos, hasta espinas de la corona de Cristo crucificado.

Para este tiempo apareció un texto de espiritualidad, que marcaría época y haría escuela en muchos cristianos, incluso en personas que en el futuro serían declarados santos por la Iglesia Católica. Se trata de la "imitación de Cristo" de Tomás de Kempis. Específicamente, el libro II, capitulo 12 está dedicado al tema de "la santa cruz" -fíjense que ya aquí se le da a la cruz el apelativo de "santa", a 
pesar de ser instrumento originalmente de martirio- algunos fragmentos versan así: .

1. Esta palabra parece dura a muchos: Niégate a ti mismo, toma tu cruz, y sigue a Jesús. Pero mucho más duro será oír aquella postrera palabra: Apartaos de mí, malditos, al fuego eterno. Pues los que ahora oyen y siguen de buena voluntad la palabra de la cruz, no temerán entonces oír la palabra de la eterna condenación.

Esta señal de la cruz estará en el cielo, cuando el Señor vendrá a juzgar.

Entonces todos los siervos de la cruz, que se conformaron en la vida con el crucificado, se llegarán a Cristo juez con gran confianza.

2. [...] En la cruz está la salud, en la cruz la vida, en la cruz está la defensa de los enemigos, en la cruz está la infusión de la suavidad soberana, en la cruz está la fortaleza del corazón, en la cruz está el gozo del espíritu, en la cruz está la suma virtud, en la cruz está la perfección de la santidad.

[...] Toma, pues, tu cruz, y sigue a Jesús, e irás a la vida eterna.

El vino primero, y llevó su cruz y murió en la cruz por ti; porque tú también la lleves, y desees morir en ella.

Porque si murieres juntamente con El, vivirás con El.

Y si fueres compañero de la pena, lo serás también de la gloria.

3. Mira que todo consiste en la cruz, y todo está en morir en ella.

Y no hay otra vía para la vida, y para la verdadera entrañable paz, sino la vía de la santa cruz y continua mortificación.

1 El texto completo fue escrito sobre pergamino por Tomás de Kempis antes de 1441, y ha llegado hasta nosotros gracias al manuscrito original de su autor, actualmente en la Biblioteca Real de Bruselas. Puede encontrarse el texto completo en http://www.samaelgnosis.net/libro/ pdf/imitacion_cristo.pdf 
Ve donde quisieres, busca lo que quisieres, y no hallarás más alto camino en lo alto, ni más seguro en lo bajo, sino la vía de la santa cruz. [...] (Kempis).

Nótese en la siguiente parte, que se abandona el tema de la cruz y sus referencias evangélicas, y se pasa al tema del sufrimiento como algo querido por Dios:

4. A veces te dejará Dios, a veces te perseguirá el prójimo: lo que peor es, muchas veces te descontentarás de ti mismo, y no serás aliviado, ni refrigerado con ningún remedio ni consuelo; mas conviene que sufras hasta cuando Dios quisiere.

Porque quiere Dios que aprendas a sufrir la tribulación sin consuelo, y que te sujetes del todo a Él, y te hagas más humilde con la tribulación.

Ninguno siente así de corazón la pasión de Cristo, como aquel a quien acaece sufrir cosas semejantes.

Así que la cruz siempre está preparada, y te espera en cualquier lugar; no puedes huir dondequiera que estuvieres, porque dondequiera que huyas, llevas a ti contigo, y siempre hallarás a ti mismo. [...].

5. Si de buena voluntad llevas la cruz, ella te llevará, y guiará al fin deseado, adonde será el fin del padecer, aunque aquí no lo sea.

[...] Si desechas una cruz, sin duda hallarás otra, y puede ser que más grave.

6. ¿Piensas tu escapar de lo que ninguno de los mortales pudo?

¿Quién de los Santos fue en el mundo sin cruz y tribulación?

Nuestro Señor Jesucristo por cierto, en cuanto vivió en este mundo, no estuvo una hora sin dolor de pasión.

Porque convenía, dice, que Cristo padeciese, y resucitase de los muertos, y así entrase en su gloria.

Pues ¿cómo buscas tú otro camino sino este camino real, que es la vida de la santa cruz? 
7. Toda la vida de Cristo fue cruz y martirio, y tú ¿buscas para ti holganza y gozo?

Yerras, te engañas si buscas otra cosa sino sufrir tribulaciones; porque toda esta vida mortal está llena de miserias, y de toda parte señalada de cruces. Y cuanto más altamente alguno aprovechare en espíritu, tanto más graves cruces hallará muchas veces, porque la pena de su destierro crece más por el amor.

8. [...] Y algunas veces tanto es confortado del afecto de la tribulación y adversidad, por el amor y conformidad de la cruz de Cristo, que no quiere estar sin dolor y tribulación: porque se tiene por más acepto a Dios, cuanto mayores y más graves cosas pudiere sufrir por El. [...].

9. No es según la condición humana llevar la cruz, amar la cruz, castigar el cuerpo, ponerle en servidumbre; huir las honras, sufrir de grado las injurias, despreciarse a sí mismo, y desear ser despreciado; sufrir toda cosa adversa y dañosa, y no desear cosa de prosperidad en este mundo. [...].

10. Dispónte, pues, como buen y fiel siervo de Cristo, para llevar varonilmente la cruz de tu Señor crucificado por tu amor.

Prepárate a sufrir muchas adversidades y diversas incomodidades en esta miserable vida; porque así estará contigo Jesús adondequiera que fueres; y de verdad que le hallarás en cualquier parte que te escondas.

Así conviene que sea, y no hay otro remedio para evadirse del dolor y de la tribulación de los males, sino sufrir.

Bebe afectuosamente el cáliz del Señor, si quieres ser su amigo, y tener parte con El. Remite a Dios las consolaciones, para que haga con ellas lo que más le agradaré.

Pero tú dispónte a sufrir las tribulaciones, y estímalas por grandes consuelos; porque no son condignas las pasiones de este tiempo para merecer la gloria venidera, aunque tú solo pudieses sufrirlas todas. 
11. Cuando llegares a tanto, que la aflicción te sea dulce y gustosa por amor de Cristo, piensa entonces que te va bien; porque hallaste el paraíso en la tierra. [...].

12. Si te dispones para hacer lo que debes, es a saber, sufrir y morir, luego te irá mejor, y hallarás paz. [...].

[...] Así que leídas y bien consideradas todas las cosas, sea esta la postrera conclusión: Que por muchas tribulaciones nos conviene entrar en el reino de Dios (Kempis).

No parece necesario hacer una hermenéutica del texto, éste habla por sí mismo; más bien podemos recurrir a un texto de Ignacio Ellacuría, que resulta iluminador como crítica a esta manera de concebir una espiritualidad dolorista de la cruz, que funge como salida y escape al compromiso desde la cruz por los sufrientes del mundo:

El enfoque ascético y moralista de la cruz cristiana desvirtuó la importancia histórica de la cruz y suscitó un rechazo de todo lo que tenga que ver con ella. Tal rechazo está plenamente justificado, caso de que no responda a una salida inmadura de quien se libera de sus fantasmas emocionales. La renovación del misterio de la cruz poco tiene que ver con la represión gratuita, que coloca a la cruz donde quiere cada uno y no donde fue colocada por Jesús, como si él hubiera buscado para sí la muerte y no el anuncio del reino (Ellacuría \& Sobrino, 1990).

Es claro, como lo nota Ellacuría, que esta espiritualidad medieval basada en una idea dolorista de la cruz, ha desvirtuado "la importancia histórica de la cruz". La religión, como sistema ideológico, ha desvirtuado la cruz, la ha sacado de su contexto original: la revelación; y la ha ubicado en el terreno en el que el ser humano ha hecho del miedo a la ira de Dios, la fuerza que lo impulsa a agradar a ese Dios "eternamente enojado". La fenomenología de la religión nos puede dar una mano en este punto, y nos ayuda a ver las numerosas manifestaciones de esta idea de la exaltación de la cruz, como camino privilegiado de reparación en el que se legitima el sufrimiento.

François Varone, precisamente, afirma que la religión

Es, por tanto, la relación hombre-Dios, en la que el hombre, intensamente consciente de su debilidad física y moral y del poder divino, 
pretende actuar sobre éste para hacerle reaccionar a favor de aquella. Al ser débil -por definición extraída de la experiencia social-, carente de poder y, sobre todo, de interés para el poderoso, le es menester, por tanto, desplegar medios y dones y emprender acciones y sacrificios para llegar como sea al poderoso (Varone, 1988).

Hace notar Varone que en la base misma de esta comprensión de la religión, aparece la palabra "sacrificio"; ella constituye esencialmente la experiencia religiosa, y hace "pujar" cada vez más fuerte al hombre hacia Dios, hasta lograr el sacrificio humano; solo así se alcanza la cima de la religión (Varone, 1988). En este sentido es que se debe entender la perversión que se ha hecho del sacrificio de Jesús, al que se le ha hecho una interpretación aberrante.

En efecto, ante la "ofensa infinita" que el hombre le ha hecho a Dios, y que le ha valido la pérdida de su condición paradisíaca, es necesario reparar el daño; pero

El hombre, aunque llegara a ofrecer la vida misma en desagravio, no estaría ofreciendo en realidad nada, puesto que había merecido la muerte con creces, de modo que fue Cristo quien decidió entregar su vida a Dios en el Calvario. Ahora las cosas cambian. La justicia exigía que el Padre recompensara a su Hijo el sacrificio que acababa de realizar, y -como éste no necesitaba nada para sí mismo- pidió que su mérito fuera transferido a los hombres. De esta forma Jesús hizo posible que el Padre perdonara a la humanidad (Luis, 1258) (Carvajal L. S., 1989).

Esta doctrina es conocida como "satisfacción vicaria", y su formulación se debe a san Anselmo en el siglo XI. La lógica del obispo de Canterbury, consiste en que el hombre ya no puede dar nada de sí para satisfacer a Dios, que esta airado por la ofensa; ni siquiera puede dar la vida, ya que ésta se encuentra "hipotecada" como precio impuesto por Dios, como consecuencia del mismo pecado de Adán y Eva. Dios ha quitado a los seres humanos el don de la inmortalidad con el que los había creado, y de ahora en adelante tendrán que morir. Se precisa entonces un inocente. El Hijo de Dios cumple con esa inocencia y su muerte podrá ser totalmente satisfactoria (Varone, 1988).

En la modernidad, la crítica a esta doctrina fue implacable. Muchos ateos consideraron que la salvación expresada y entendida en esos términos es "una salvación que no salva" (VARONE, 1988, p. 21); porque "en rigor se trata de una salvación para Dios -el cual no tiene ninguna necesidad de ella-, porque es él el 
que es liberado de su ira, aplacado en su deseo de venganza y satisfecho en su justicia. [...] Por tanto, en realidad es Dios quien se salva a sí mismo" (Varone, 1988).

El testimonio de dos ateos tal vez ilumine mejor esta idea. Lin Yutang, un cristiano chino que luego perdería su fe, encontraba desproporcionado que Dios se enojara con el hombre por comer un fruto, y que luego quedara encantado de que le hubieran matado a su hijo. El texto dice:

Aún más absurda me pareció otra proposición. Se trata del argumento de que cuando Adán y Eva comieron una manzana durante su luna de miel, se enfureció tanto Dios que condenó a su posteridad a sufrir de generación en generación por ese pequeño pecado, pero que cuando la misma posteridad mató al hijo del mismo Dios, Dios quedó encantado que a todos perdonó (Carvajal L. S., 1989).

Si Dios aparece, no como el Padre bondadoso que perdona y salva por pura gracia, sino que pareciera el "obstáculo que hay que vencer para conseguirla", debemos escuchar seriamente a Nietzche que afirmaba:

No conocían otra manera de amar a su Dios que clavando a los hombres en la cruz. Pensaron vivir como cadáveres y vistieron de negro su cadáver; hasta en su discurso percibo todavía el olor malo de las cámaras mortuorias Mejores cánticos tendrían que cantarme para que aprendiese a creer en su Redentor y más redimidos tendrían que parecerme sus discípulos (Nietzche, 1970).

En otras de sus conocidas críticas Nietzche decía:

La Iglesia combate la pasión con la extirpación, en todos los sentidos de la palabra: su medicina, su "cura" es el castradismo [...] atacar las pasiones en su raíz significa atacar la vida en su raíz: la praxis de la Iglesia es hostil a la vida [...] (Nietzche1982).

¡Yo os conjuro, hermanos míos, permaneced fieles a la tierra y no creáis a quienes os hablan de esperanzas sobre terrenales! Son envenenadores, lo sepan o no. Son despreciadores de la vida, son moribundos y están, ellos también, envenenados, la tierra está cansada de ellos: ¡jala desaparezcan! (Nietzche, 1970)

Así las cosas, se hace necesario repensar la teología de la redención, y con ella la teología de la cruz. Es urgente liberar esta teología, que ha puesto el 
sufrimiento en el centro de la redención, y lo pone en el centro al amor como medida de toda entrega. Será necesario enfatizar en -la espiritualidad del compromiso [que] recupera la memoria del crucificado, evitando que la cruz sea desvirtuada" (Herminio Gil, 1984)-. Será necesario liberar la cruz de todo imaginario sentimentaloide para devolverle su fuerza histórica, que no es otra que la conciencia de que Jesús murió en la cruz, para que nunca más hayan crucificados en la tierra.

\section{"Bajar de la cruz a los pobres": teología de la cruz liberada}

¿Cómo predicar hoy la cruz en una sociedad de crucificados?

Hay pocos temas que se hayan prestado tanto a la manipulación ideológica y a la justificación de la humillación y del sometimiento como el de la cruz y el de la muerte. Existen interpretaciones de la Pasión de Cristo, introducidas por la piedad y por la homilética cristiana, que magnifican la cruz por la cruz y terminan en un dolorismo que desarma la lucha de los cristianos contra los mecanismos productores de dolor y de cruz (Boff,L. 1984).

Este breve fragmento es de Leonardo Boff, quien ha sido uno de los teólogos de la liberación más preocupados por el tema de la teología de la cruz, en la tradición teológica latinoamericana. Su primer trabajo dedicado al tema fue Paixão de Cristo, Paixão do mundo, de la editorial Vozes, en 1977; publicado después en español en 1981 como Pasión de Cristo, Pasión del Mundo, de la editorial Sal Terrae. $\mathrm{Al}$ año siguiente -1981- apareció en la editorial Cristiandad, el trabajo titulado Jesucristo y la liberación del hombre. Ambos textos, dedicados ampliamente a la problemática de la teología de la cruz, intentan poner el acontecimiento de la muerte de Jesús en su legítimo lugar histórico y su significado teológico, es decir, poner la muerte de Jesús en el conjunto de su obra salvadora, al lado de la encarnación y la venida del Reino de Dios. Así mismo, Boff pretende interpretar el acontecimiento de la muerte para que su predicación tenga validez también hoy, donde hay tantos hombres y mujeres en situación de crucificados.

Por lo que hemos documentado en esta investigación, el origen de toda esta preocupación de Leonardo Boff por el tema de la cruz, y su relación con la doctrina de la redención, es aquella anécdota que narramos en la introducción de este 
texto. Boff, una vez escuchó a los campesinos manifestar que Jesús nos había salvado con su muerte en la "bendita santa cruz", se preguntaba ¿por qué el pueblo asocia inmediatamente redención y cruz? Y se respondía

Ciertamente, porque no le fue enseñado el carácter procesal de la redención, es decir el carácter histórico, (la redención es un proceso histórico) del hombre que se va liberando. Tal vez sea porque su propia vida es principalmente sufrimiento y cruz; un sufrimiento y una cruz que la sociedad le coloca sobre los hombros a los pobres y al pueblo. Pero un Jesús que sólo sufre no libera; un Jesús doloroso no libera: genera fatalismo y dolorismo, nada más (Segundo, 1982).

Juan Luis Segundo, comentando este texto de Boff, afirma que el teólogo brasilero fue capaz de hacer una hermenéutica de la sospecha, para descubrir que "la sociedad le hace cargar al pobre con la cruz y le dice después que Jesús hizo lo mismo y con eso mantiene al pueblo con la cruz. Entonces, ese Dios que el pueblo coloca en todas sus luchas no es el de la teología cristiana, sino el de la ideología que la sociedad le ha impuesto"(Segundo, 1982).

En páginas anteriores realizamos una crítica a la tradicional doctrina de la redención según san Anselmo, ayudados de François Varone. También Leonardo Boff hace su crítica a esta teoría y lanza una serie de preguntas, que exigen de nosotros respuestas críticas y renovadoras.

Las imágenes y representaciones que la piedad, la liturgia y la teología emplean para expresar la liberación de Jesucristo, ¿resaltan o, por el contrario, ocultan hoy para nosotros el aspecto verdaderamente liberador de la vida, muerte y resurrección de Cristo? Decimos que Cristo nos redimió con su sangre, expió satisfactoriamente con su muerte nuestros pecados y ofreció su propia vida como sacrificio para la redención de todos. Pero ¿qué significa realmente todo eso? ¿Comprendemos lo que decimos? ¿Podemos de verdad pensar que Dios estaba airado y que se apaciguó con la muerte de su Hijo? ¿Puede alguien sustituir a otro, morir en su lugar y continuar el hombre con su pecado? ¿Quién tiene que cambiar: Dios o el hombre? ¿Debe Dios cambiar su ira en bondad o es el hombre el que ha de convertirse de pecador en justo? Confesamos que Cristo nos liberó del pecado, y nosotros continuamos pecando. Decimos que nos libró de la muerte, y seguimos muriendo. Que nos reconcilió con Dios, y permanecemos en su enemistad. ¿Cuáles el sentido concreto y verdadero de la liberación de la muerte, del pecado 
y dela enemistad? El vocabulario empleado para expresar la liberación de Jesucristo refleja situaciones sociales muy concretas, lleva consigo intereses ideológicos y articula las tendencias de una época. Así, una mentalidad marcadamente jurídica hablará en términos jurídicos y comerciales de rescate, de redención de los derechos de dominio que Satán tenía sobre el pecador, de satisfacción, demérito, de sustitución penal, etc. Una mentalidad cultual se expresará en términos de sacrificio, mientras otra preocupada con la dimensión social y cultural de la alienación humana predicará la liberación de Jesucristo (Boff, 1981).

Para intentar responder a estas preguntas, Boff hará un recorrido por las distintas "teologías modernas de la cruz"; pasando por Moltmann, Von Balhtasar, Metz, entre otros. Boff hace una sistematización de estas posturas, y concluye con algunas "convergencias y divergencias" de estas teologías. Relacionamos aquí algunas:

1. "Un Dios que no sufre no libera del sufrimiento"

2. “Un Dios muere. ¿De qué Dios se trata?"

3. “¿Crucifica Dios a su Hijo?”

4. "Dios doliente: ¿cómo sufre Dios?"

Estas cuatro ideas que aparecen como comunes entre todas las teologías modernas de la cruz, también presentan algunas dificultades y objeciones. Resaltamos algunas de ellas, en palabras del mismo Leonardo Boff:

1. Esto supone el paso de un Dios estático, apático (que no sufre) a un Dios vivo, patético (que tiene pathos y puede sufrir). En esto coinciden todos los autores. Como afirma Bonhoeffer, un Dios que no sufre no puede liberarnos. Pero el problema reside en cómo entender el sufrimiento de Dios. ¿Cómo hablar sobre él?

2. ¿Se puede incorporar el sufrimiento y aproximar la muerte a Dios hasta conseguir que Dios pase a ser sujeto y no sólo objeto del sufrimiento y del dolor causados por otros (Dios activo: produce el dolor en el mundo; Dios pasivo: sufre el dolor del mundo, se solidariza con él)? Aquí comienza el gran problema.

c. Tanto Moltmann como Balthasar hacen esa afirmación para resaltar la cruz como escándalo. Aquí no se sabe ya si la cruz es escándalo frente a una comprensión humana (religiosa de los judíos o filosófica de los griegos) o debe ser un escándalo tan absoluto que lo sea también para Dios. Parece que se afirma todo para romper con cualquier posibilidad de que funcione el logos. No hay ningún control ni cabe apelar a ninguna instancia. Es un hecho bruto. Nos hallamos ante el dogmatismo más radical. Tal dogmatismo está a un paso del ateísmo. El 
fideísmo y el ateísmo tienen la misma estructura. Así se explica que no haya nada que permita soslayar un ateísmo total o reducir el cristianismo aun dogmatismo fanático que se afirma como pura voluntad de poder. Presentarla realidad de la cruz como liberación y crítica de todos los proyectos liberadores es la forma de universalizar una esclavitud. Se libera haciendo a todos esclavos de un concepto tiránico de Dios.

d. El equívoco de esta teología, que proyecta sin matices el dolor y la cruz sobre el mismo Dios, radica en presentar al Padre como asesino de Jesús. [...] Si Dios se calla ante el dolor es porque él mismo padece y hace suya la causa de los martirizados y de los que sufren (cf. Mt 25,31). El dolor no le es ajeno; pero si lo asumió no fue para eternizarlo y dejarnos sin esperanza, sino porque quiere poner fin a todas las cruces de la historia.

e. Decir que Dios es amor es afirmar su vulnerabilidad. En otras palabras: Dios ama y puede ser correspondido o rechazado [...] Sin embargo, no debemos atribuir a Dios los mecanismos que generan el dolor, la cruz, la división y el odio entre los hombres. En una palabra: no podemos unir a Dios y a la cruz hasta situar la cruz en la identidad divina. Si fuera así, estaríamos perdidos. Si el mismo Dios sufre en su esencia, si Dios odia, si Dios crucifica, nos quedamos sin salvación. Porque él sería a la vez bueno y malo, y nosotros estaríamos sometidos a la eterna alternancia del bien y el mal. ¿Cómo hablar de una redención si Dios mismo debe redimirse? (Boff, 1981).

Ante las objeciones a esta manera de hacer teología de cruz, muy europea, Boff considera que esta teología debe ponerse en el lugar correcto. De ahí que haga notar que la cruz posee dos caras; "es instrumento cruel de castigo para los rebeldes políticos o para los esclavos [ ] [pero a la vez] la cruz encarna uno de los símbolos más poderosos del cristianismo como expresión de la redención de Cristo y de la voluntad salvífica del Padre" (Boff, 1984, p. 11). De ahí que para Boff sea tan difícil hacer una correcta teología de la cruz, ya que la cruz misma puede ser motivo de negación del proyecto de Dios, en cuanto lugar de frustración de ese proyecto, pero "al mismo tiempo, como precio a pagar por la realización del proyecto de este Dios vivo, en las condiciones presentes de la historia decadente" (Boff, 1984, p. 11).

A su vez, Raúl Pariamachi, hace ver que lograr poner en su justa medida estas dos caras de la teología de la cruz, es uno de los grandes logros de la cristología latinoamericana; pues "ha contribuido a reconstruir la imagen del Cristo sufriente en América Latina, en tanto que la ha reinterpretado en clave liberadora. Esta cristología aborda la cruz de Jesús enfatizando la estrecha relación entre la pregunta 
histórica por la causa de su muerte (¿por qué mataron a Jesús?) y la pregunta teológica por el sentido de su muerte (¿por qué murió?)” (Pariamachi, 2012).

Esta contribución cristológica latinoamericana gira en torno a dos ejes: la Pasión de Cristo y la Pasión del hombre de hoy, que Boff considera como "dos misterios insondables: - el de la Pasión de Cristo, y- el del sufrimiento humano" (Boff, 1984). Pero a su vez distingue tres tipos de cruces: “Una cruz 'natural', es decir, inherente al ser humano"; que se verifica en la condición ontológica como destino hacia la muerte. Una segunda cruz es aquella que seres humanos ponen a cargar a otro seres humanos, producto de estructuras de pecado; y una tercera cruz que es la que libremente se opta cargar como consecuencia de la coherencia con la que se vive el evangelio (Boff, 1984).

La primera cruz es inevitable, y es legítimo predicarla e incorporarla en nuestro proyecto de vida; hay que aprender a asumirla desde la fe y la esperanza en el reino futuro. La segunda cruz, fruto del pecado, es la que debemos combatir, denunciar y tratar de eliminar definitivamente, ya que es contradicción con el proyecto de Dios y por lo tanto de todo ser humano. Esta es una cruz que ha dejado pobres y excluidos a millones de indígenas, afrodescendientes, campesinos, mujeres, homosexuales y muchos otros, considerados "no-personas". La tercera cruz "es consecuencia de optar por la causa de los crucificados, la de ser coherente con el proyecto de vida. Esa fue la de Jesús" (Boff, 1984). En este sentido

Cargar la cruz como Jesús la cargó significa, por tanto, solidarizarse con aquellos que son crucificados en este mundo: los que sufren violencia, son empobrecidos, deshumanizados, ofendidos en sus derechos. Defenderlos, atacar las prácticas en cuyo nombre son hechos "no-personas", asumir la causa de su liberación, sufrir por causa de esto; he ahí lo que es cargar la cruz. La cruz de Jesús y su muerte fueron consecuencia de este compromiso por los desheredados de este mundo (Boff, 1978).

Si bien es cierto, como lo dijimos antes, Leonardo Boff se destaca por ser uno de los teólogos de la liberación que más trabajó el tema de la teología de la cruz, y por eso dedicamos un amplio espacio a destacar algunos de sus aportes, también es cierto que Jon Sobrino hizo grandes aportes al tema. Por eso queremos dedicar un espacio para mostrar su aporte.

Con el título de "El Resucitado es el Crucificado". Lectura de la resurrección de Jesús desde los crucificados del mundo, Jon Sobrino había publicado en 1982 un trabajo monográfico dedicado al tema de la resurrección. Este trabajo apareció después como un capitulo en la obra Jesús en América Latina. Su significado para la fe y la 
cristología. Desde el inicio del texto, Sobrino enuncia el objetivo de su trabajo. "Son estos crucificados de la historia los que ofrecen la óptica privilegiada para captar cristianamente la resurrección de Jesús y hacer una presentación cristiana de ella. Esto es lo que pretendemos hacer a continuación" (Sobrino, 1995). Aquí aparece entonces, una idea que habíamos anunciado ya al iniciar este trabajo, y es la importante conexión que la TdL quiere hacer notar entre crucifixión y resurrección, y que explica de alguna manera la escasa producción teológica sobre la cruz. Jon Sobrino lo expone así:

La resurrección de Jesús no es entonces sólo símbolo de la omnipotencia de dios, como si Dios hubiese decidido arbitrariamente y sin conexión con la vida y destino de Jesús mostrar su omnipotencia. La resurrección de Jesús es presentada más bien como la respuesta de Dios a la acción injusta y criminal de los hombres (Sobrino1995).

Queda claro que la TdL quiere mostrar que lo definitivo en el proyecto de Jesús no fue su muerte, sino la reivindicación de la victima; por eso Sobrino dirá que "la actual teología de la resurrección ha superado acertadamente la concepción dolorista del cristianismo"; por lo tanto, "la resurrección de Jesús es esperanza en primer lugar para los crucificados. Dios resucitó a un crucificado, y desde entonces hay esperanza para los crucificados de la historia" (Sobrino 1995).

Para Jon Sobrino, la fuerza de la cruz no estáen lo que la hemos convertido en la religiosidad popular, en la cruz -en singular-, en el objeto esotérico que colgamos o cargamos en nuestro cuerpo, con la esperanza de tener suerte o protección. Para Sobrino la cruz de Jesús es una cruz -una de tantas cruces de la historia- y por eso se convierte en esperanza para una inmensa mayoría de hombres y mujeres crucificados después de él (1995, p. 240).

Aquí aparece nuevamente la intuición de Ignacio Ellacuría, que es definitivamente asumida por todos los teólogos de la liberación: la cruz de Jesús y su significado teológico solo puede entenderse correctamente, si recuperamos la fuerza histórica del acontecimiento pasión y resurrección. Desconectada de la historia y del proyecto de Jesús, la cruz se convierte en caricatura y acicate de malos entendidos para nuestra religiosidad, nuestra espiritualidad, y peor aún, sólo servirá a la parálisis de nuestro compromiso con los crucificados del mundo.

Terminamos afirmando una vez más lo que enuncia el título de este trabajo. Que frente al peligro de secuestrar el auténtico significado de la cruz y el sufrimiento del crucificado, trátese de Jesús o de cualquier otro crucificado del mundo. Es necesario emprender un camino de liberación de una teología de la cruz 
dolorista, hacia una teología que aporte decididamente a bajar a las víctimas de las cruces, aquéllas que esta sociedad excluyente a labrado para miles de mujeres y hombres victimizados. Hay que liberar cualquier interpretación de que Dios quiso la muerte del hijo. Dios no quiere el sufrimiento ni del hijo ni de ningún ser humano, Dios quiere la fidelidad a su reino aunque eso implique la muerte, sólo así el mártir se verá rehabilitado por el mismo Dios en la resurrección. Ella debe ser entendida como la reivindicación de la víctima, como el triunfo de Dios sobre el pecado, que nunca tendrá la última palabra (Boff, 1986).

\section{Referencias}

(s.f.). Obtenido de http://www.samaelgnosis.net/libro/pdf/imitacion_cristo.pdf

Berder, M., \& otros. (2004). El sacrificio de Cristo y de los cristianos. Navarra: Verbo Divino.

Boff, L. (s.f.). Obtenido de www.servicioskoinonia.org/relat217

Boff, L. (1977). Paixão de Cristo, Paixão do mundo. Petrópolis: Vozes.

Boff, L. (1981). Jesucristo y la liberación del hombre. Madrid: Cristiandad.

Boff, L. (1981). Pasión de Cristo, Pasión del Mundo. Santander: Sal Terrae.

Boff, L. (1984). ¿Cómo predicar hoy la cruz en una sociedad de crucificados?. Staurós(5, 11).

Boff, L. (1986). Teología desde el lugar del pobre. Santander: Sal Terrae.

Carvajal, L. S. (1989). Esta es nuestra fe. Teología para universitarios. Santander: Sal Terrae.

Ellacuría, I., \& Sobrino, J. (1990). Mysterium Liberationis. Conceptos fundamentales de la teología de la liberación. Madrid: Trotta.

Herminio Gil. (1984). Cristianos de América latina cuentan sus experiencias de dolor. Staurós $(5,6)$.

Machuca, A. V. (1977). Jesucristo en la historia y en la fe. Semana internacional de teología. Salamanca: Sígueme.

Pagola, J. A. (2007). Jesús. Aproximación histórica. Madrid: PPC.

Raúl Pariamachi. “"', E. (s.f.). Recuperado el 2012, de http://www.adital.com.br/site/ noticia2.asp?lang=ES\&cod $=25631$

Segundo, J. L. (1982). Iglesia, 20 años después del concilio, (págs. 48-49). Montevideo. Obtenido de http://www.snips.com/web/JuanLuisSegundo/ 
Segundo, J. L. (1989). El Dogma que Libera. Fe, Revelación y Magisterio Dogmático. Santander: Sal Terrae.

Sobrino, J. (1982). Jesús en américa Latina. Su significado para la fe y la cristología. Santander: Sal terrae.

Sobrino., J. (1982). El Resucitado es el Crucificado. Lectura de la resurrección de Jesús desde los crucificados del mundo. Santander: Sal Terrae.

Varone, F. (1988). El "dios" sádico. ¿Ama Dios el sufrimiento? Santander: Sal Terrae.

XVI, B. (2008). La teología de la cruz en la predicación de San Pablo. Ciudad del Vaticano. 